\title{
Combating the impact of COVID- 19 on Public University Students through Subsidized Online Class: Evidence from Bangladesh
}

\author{
Dr Farhana Begum ${ }^{1 *}$ Dr Syed Zabid Hossain ${ }^{2}$ Dr Md. Shahinul Alam ${ }^{3}$ Ummay Nayeema Islam ${ }^{4}$ Habjul \\ Alam Lemon ${ }^{5}$ Professor Dr. Normah Binti Omar ${ }^{6}$ \\ 1. Assistant Professor in Accounting, Directorate of Secondary and Higher Education, Ministry of Education, \\ Dhaka, Bangladesh \\ 2. Professor ,Department of Accounting and Information Systems, University of Rajshahi, Bangladesh \\ 3. Professor, Department of Hepatology, Bangabandhu Sheikh Mujib Medical University, Dhaka. Bangladesh \\ 4. Statistics, University of Dhaka, Bangladesh \\ 5. Lecturer, Department of Accounting, Sherpur Govt. College, Bangladesh \\ 6. Professor, Director, Accounting Research Institute (ARI HICoE), Level 12, Menara SAAS, Universiti \\ Teknologi, MARA (UiTM), 40450 Shah Alam, Selangor MALAYSIA \\ * E-mail of the corresponding author: farhanaju@yahoo.com
}

\begin{abstract}
We strived to explore the impact of COVID-19 pandemic on public university students with barriers to the online class through surveyed 1092 students of 15 public universities in Bangladesh using Google Form. Eight barriers were explored. About half, 542(49.6\%) students shouldered learning-related costs, 489(45\%) students had part time job, 461(42.2\%) had COVID-19 patients nearby, 805(73.7\%) faced income reduction, 367(75.2\%) lost parttime jobs and $688(63 \%)$ had financial crises, 703(64.3\%) deterioration of psychological status, $827(75.7 \%)$ had internet access and 526(48.2\%) had devices to attend online classes but $519(47.5 \%)$ failed to bear the internet cost. Besides, the study time reduced significantly from $(3.67 \pm 2.17)$ to $(1.23 \pm 1.34)$ hours, and career planning of 853(78.2\%) struck. COVID-19 has multiple catastrophic impacts on the educational, financial, and psychological aspects. To curb these impacts, public universities must provide financial subsidies to those disadvantaged students to ensure the success of the online class.
\end{abstract}

Keywords: Covid-19, Education, Public University, Financial crisis, Online Class, Subsidy

DOI: $10.7176 / \mathrm{JEP} / 11-27-17$

Publication date:September $30^{\text {th }} 2020$

\section{Introduction}

COVID-19 is the pandemic disease caused by newly emergent corona virus declared by the World Health Organization (WHO) on 11th March, 2020 (World Health Organization, 2020). The first outbreak started in Wuhan City, Hubei Province, China, in December 2019. Globally 212 countries are affected and the disease is spreading rapidly with total cases and deaths increasing everyday (Directorate General of Health Services, 2020; Bender, 2020). In Bangladesh, COVID-19 infections are around 331078 cases with 4593 deaths until 9 September, 2020 (Directorate General of Health Services, 2020).

This pandemic has affected educational systems worldwide, leading to the near-total closures of schools, universities and colleges. According to UNESCO monitoring, 191 countries have implemented nationwide closures and 5 have implemented local closures, impacting about 98.4 percent of the world's student population affecting approximately 1.723 billion learners (Mustafa, 2020; World Bank Group, 2020; United Nations Educational, Scientific and Cultural Organization, 2020). The universities like MIT, Oxford, Harvard, Stanford, Cambridge, Caltech, and Chicago are compelled to stop academic activity (Askari, 2020). The education activities of the universities in Bangladesh is being stopped as a result of COVID-19 pandemic fallout. All educational institutions in Bangladesh have been closed since March 17, 2020 and if the situation does not improve it may remain closed till September as announced by the Honorable Prime Minister. Due to uncertainty of COVID-19, it is not yet certain when the education institutions of Bangladesh will be reopened. Prolonged lockdown and closure of educational institutions may negatively impact educational, socioeconomic, financial and psychological aspect of university students (World Health Organization, 2020). After the independence in 1971, Bangladesh has suffered with numerous natural disasters. In turn, the country has bounced back from the situations strongly in most of the 
cases, and since the early 2000's the country has made significant improvement in economic development indicators in South Asia. However, this is the first time the country is embracing the novel Corona virus (COVID19) that is throttling the local and global economy as well (Rahman \& Rahman, 2020; Cambridge Assessment International Education.2020).

UNESCO is providing immediate support to countries as they work to minimize the educational disruption and facilitate the continuity of learning, especially for the most vulnerable (United Nations Educational, Scientific and Cultural Organization, 2020). Even during the corona virus pandemic most of the education institutions in China, South Korea, Singapore, The Kingdom of Saudi Arabia, Malaysia, Australia, The United Kingdom, the United States of America and member of the European union have continued their education by taking classes online or digitally for smoothing arrangement of the academic session (Yee,2020). Due to the COVID-19 pandemic, higher educational institutions of the world are shifting to online learning or distance education programs. The advantage is it can allow for the students to learn at their convenience since it is needless to attend training centers and universities (Knebel, 2001). The increasing use of this technology in education has modified teachers' methods from the traditional approach (Onyema et al., 2019) and facilitates remote learning, distance learning, virtual learning, blended learning, mobile learning and distributed learning. The use of appropriate educational technologies increases accessibility to learning resources with certain challenges (Onyema.et al., 2020).

Public universities of Bangladesh are almost fully dependent on government funding and logistics and infrastructures for online class may be of limited. Accessibility, availability, quality of internet and shortage of devices may be of those but the spectrum and depth of challenges for student of public universities is not yet estimated in Bangladesh and a study found that the students in public universities of Bangladesh relatively lower satisfaction than that of private universities of Bangladesh (Mazumder , 2014).

With this background we have designed this study to estimate the volume of impact of COVID-19 on students of public universities of Bangladesh regarding educational, financial and psychological issues. This study aimed also to explore the availability and accessibility of internet and devices for online class for the student to overcome the impact and challenges.

\section{Data and methods}

\subsection{Data source and sample}

Bangladesh is divided into eight administrative divisions. Universities were selected from each division. A sample size was calculated to make it sufficient and representative. The study conducted convenience sampling design. An online survey method by using Google Form Survey was carried out for the purpose of the study. In terms of defining the sample, the first and foremost criterion was that the respondent should be a student of public university in Bangladesh. A total of 1112 responses were found but researcher included 1092 students since the rest 20 respondents had invalid answers.

This instrument contained 24 items which sought information related to demographic, psychological, financial crisis of a student. The tool also included various information about online classes and took opinion from the students on this context. Most of the questions are closed ended. Questions like "impact of sudden discontinuity on career planning" or " impact on study" included five categories of responses- extremely negative, negative, unchanged, positive and extremely positive. At first, pretesting of the questionnaire was performed among 50 random respondents. The experience of piloting was used to make a final adjustment before sharing the items in the Google form with the students. Students were requested to participate in the survey by clicking the link sent to them via Facebook, Messenger, What's App, email and short message service (SMS) from 14/06/20 to 23/06/20. They filled the questionnaire using desktop computers, laptops, phones etc. Confidentiality was maintained strictly through the researchers own responsibility.

\subsection{Data cleaning and statistical analyses}

Due to automation of the Google form, fill up data were putdown into the Google drive as sheets in comma separate value (csv) format. The data sheet was cleaned, organized and imported into the statistical software SPSS 20 for final analysis. Due to nature of study, descriptive statistics were used, Independent sample t test, paired sample $t$ test and $\mathrm{x} 2$ test was done for analysis and $\mathrm{p}$ value of $<0.05$ was considered as significant. The findings were presented in the form of tables and interpreted accordingly. 


\section{Results}

In this survey held on the impacts of COVID-19 on education among the students of 15 public universities: University of Dhaka, Bangladesh University of Engineering and Technology, University of Rajshahi, University of Chittagong, Jahangirnagar University, Shahjalal University of Science and Technology, Mawlana Bhashani Science and Technology University, Chittagong University of Engineering and Technology, Jagannath University, Sylhet Agricultura University, Comilla University, Begum Rokeya University, Jaitya Kabi Kazi Nazrul Islam University, Bangladesh University of Professionals and University of Barishal.

\subsection{Demographic characteristics of respondents}

In this study out of total 1092 most of the respondents were male $732(67.4 \%), 354$ (32.6\%) were female and 06 respondents denied to answer about sex. A majority of the students were under graduate $859(79 \%), 118(10.8 \%)$ were graduate and $115(10.53 \%)$ were post graduate.

Furthermore $550(50.4 \%)$ respondents bore no portion of their educational or general living expenses. However, $138(12.6 \%)$ of respondents have replied that their educational or general living expenses were fully borne by them and $404(37.0 \%)$ of the respondents bore it was partially.

Significantly higher number of male students shoulder their full expenses (p-value 000), though 33 (9.3\%) female students had to manage their full expense by themselves, $\mathrm{X} 2(2, \mathrm{~N}=1086)=16.06, \mathrm{p}=.000$.

About half of the respondents 603 (55\%) did not have any private tuition or part time job whereas 489 (45\%) of the students had a private tuition or part time job. Higher number of male students 347 (47.4\%) were involved in private tuition or part time job than their female counterparts $138(39.0 \%)$ and the result is significant, X2 $(1, \mathrm{~N}=$ 1086) $=6.85, \mathrm{p}=.009$.

Most of the respondents 1040 (95.2\%) have no COVID-19 positive patients in their family whereas only $47(4.3 \%)$ of the respondents have COVID-19 positive patients in their family. On the other hand, $620(56.8 \%)$ respondents have no COVID-19 positive patient in their neighborhood whereas near about half 461 (42.2\%) of the respondents have COVID -19 positive patients in their neighborhood (Table 1).

Table 1. Demographical characteristics of respondents.

\begin{tabular}{|l|l|l|l|l|}
\hline $\begin{array}{l}\text { Sex } \\
\text { Male : Female n (\%) }\end{array}$ & $732(67.4)$ & $354(32.6)$ & & \\
\hline $\begin{array}{l}\text { Level of Respondents } \\
\text { Under Graduate/ Graduate/ Postgraduate n (\%) }\end{array}$ & $859(79)$ & $118(10.8)$ & $115(10.53)$ & \\
\hline Educational Expenses is borne by Respondents & Fully n (\%) & Partially n (\%) & Not at all n (\%) & $\mathrm{p}$ \\
\hline Total & $138(12.6)$ & $404(37.0)$ & $550(50.4)$ & \\
\hline Male & $103(14.1)$ & $290(39.6)$ & $339(46.3)$ & .000 \\
\hline Female & $33(9.3)$ & $112(31.6)$ & $209(59.0)$ & $\mathrm{p}$ \\
\hline Private tuition / Part time job & Yes n (\%) & No n (\%) & & \\
\hline Total & $489(45)$ & $603(55)$ & & 0.009 \\
\hline Male & $347(47.4)$ & $385(52.6)$ & & $\mathrm{p}$ \\
\hline Female & $138(39.0)$ & $216(61.0)$ & & 0.164 \\
\hline Study time before Covid & Male & Female & & \\
\hline mean \pm SD hour & $3.60 \pm 2.14$ & $3.80 \pm 2.25$ & & $1040(95.2)$ \\
\hline Covid-19 positive patient in family Yes/ No n (\%) & $47(4.3)$ & & & \\
\hline $\begin{array}{l}\text { Covid-19 positive patient in neighborhood Yes/ No } \\
\mathrm{n}(\%)\end{array}$ & $461(42.2)$ & $620(56.8)$ & & \\
\hline
\end{tabular}




\subsection{Educational, financial and psychological impact of COVID -19 on public university students}

COVID-19 had significant negative impact on education. Among the respondent ability to study reduced of 766 students. However 144 respondents said it was the same with 146 respondents who said it was in fact better and 36 saying it was much better (Figure 1).

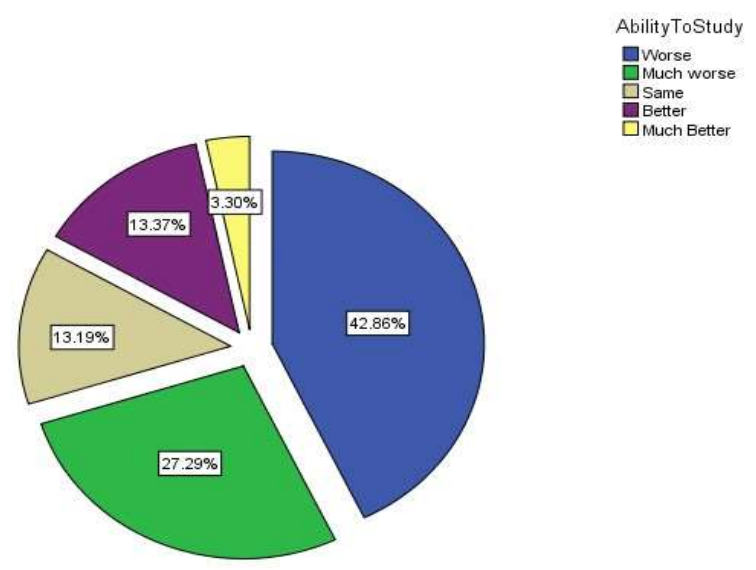

Figure 1. Impact of COVID -19 on student's ability to study from public universities

The study time was significantly reduced among the students before and during the COVID-19 pandemic from $($ Mean $\pm \mathrm{SD}) 3.67 \pm 2.17$ hours to $1.23 \pm 1.34$ hours, $\mathrm{t}(1091)=43.89, \mathrm{p}=0.000$.

COVID - 19 has had a negative impact in their career planning for $504(46.2 \%)$ of the respondents, and an extremely negative impact for $349(32.0 \%)$ of the students. However $70(6.4 \%)$ of the respondents have had a positive impact in their career planning due to COVID - 19. There has been an extremely positive impact for $14(1.3 \%)$ respondents and $155(14.2 \%)$ respondents have no change in their career planning.

It can be seen that the sudden discontinuity due to COVID-19 has had a negative impact in their life and studies for $557(51 \%)$ of the respondents and $372(34.1 \%)$ of the respondents have had an extremely negative impact in their life and studies due to the discontinuity. However, $69(6.3 \%)$ of the respondents have had a positive impact in their studies whereas $80(7.3 \%)$ of the respondents have had no change and $14(1.3 \%)$ extremely positive.

In this study it was found that income was decreased for most of the 805 (73.7\%) respondents, whereas $266(24.4 \%)$ of the students have had no change in their income. Out of 489 public university students who had private tuition or part time jobs after the coronavirus pandemic struck 367 (75.2\%) respondents have lost their part time jobs. Most of the $688(63 \%)$ respondents have answered that they are facing financial crisis. Most of the 593 students (54\%) were mentally depressed due to the financial crisis. Significantly higher number of male students 417 $(57.0 \%)$ were mentally depressed due to financial crisis than that of female student $172(48.6 \%), \mathrm{X} 2(1, \mathrm{~N}=1086)$ $=6.75, \mathrm{p}=.009$. Expenditure was also decreased for $547(50.1 \%)$ student and no change of expenditure for 366 $(33.5 \%)$ of the student. However, on the other hand expenditure was increased for $179(16.9 \%)$ of the students.

Psychological status was worsen for 494 students (45.2\%) and much worsen in 209 (19.1\%) respondents. Whereas no psychological impact was detected by themselves in $230(21.1 \%)$ respondents. 
Table 2. Educational, financial and psychological impact of COVID -19 on public university students of Bangladesh.

\begin{tabular}{|c|c|c|c|c|c|}
\hline Impact on education & $\begin{array}{l}\text { Study time before } \\
\text { COVID } 19\end{array}$ & $\begin{array}{l}\text { Study time } \\
\text { during COVID } \\
19\end{array}$ & $\mathrm{p}$ & & \\
\hline In hour $($ mean $\pm \mathrm{SD})$ & $3.67 \pm 2.17$ & $1.23 \pm 1.34$ & $.000+$ & & \\
\hline \multirow[t]{2}{*}{ Impact on career planning } & $\begin{array}{l}\text { Extremely } \\
\text { negative n }(\%)\end{array}$ & Negative $\mathrm{n}(\%)$ & $\begin{array}{l}\text { Un changed } \\
\mathrm{n}(\%)\end{array}$ & $\begin{array}{l}\text { Positive } \\
\mathrm{n}(\%)\end{array}$ & $\begin{array}{l}\text { Extremely } \\
\text { positive } n \\
(\%)\end{array}$ \\
\hline & $349(32)$ & $504(46.2)$ & $155(14.2)$ & $70(6.4)$ & $14(1.3)$ \\
\hline \multirow[t]{2}{*}{ Impact on life and study } & $\begin{array}{l}\text { Extremely } \\
\text { negative n }(\%)\end{array}$ & Negative n (\%) & $\begin{array}{l}\text { Un changed } \\
\mathrm{n}(\%)\end{array}$ & $\begin{array}{l}\text { Positive } \\
\mathrm{n}(\%)\end{array}$ & $\begin{array}{l}\text { Extremely } \\
\text { positive } n \\
(\%)\end{array}$ \\
\hline & $372(34.1)$ & $557(51.0)$ & $80(7.3)$ & $69(6.3)$ & $14(1.3)$ \\
\hline Part time job/ private tuition $\mathrm{n}(\%)$ & Continued n (\%) & Lost n (\%) & & & \\
\hline $489(44.8)$ & $121(24.8)$ & $367(75.2)$ & & & \\
\hline \multirow{2}{*}{ Financial crisis $\mathrm{n}(\%)$} & Yes n $(\%)$ & No n $(\%)$ & & & \\
\hline & $688(63.0)$ & $404(37.0)$ & & & \\
\hline \multirow[t]{2}{*}{$\begin{array}{l}\text { Mentally depressed for financial } \\
\text { crisis n (\%) }\end{array}$} & Yes n $(\%)$ & No $n(\%)$ & & & \\
\hline & $593(54.0)$ & $499(46.0)$ & & & \\
\hline \multirow[t]{2}{*}{ Impact on income } & No change $n(\%)$ & Increased n $(\%)$ & $\begin{array}{l}\text { Decreased } n \\
(\%)\end{array}$ & & \\
\hline & $266(24.4)$ & $21(1.9)$ & $805(73.7)$ & & \\
\hline \multirow[t]{2}{*}{ Impact on expenditure } & No change $n(\%)$ & Increased n $(\%)$ & $\begin{array}{l}\text { Decreased } n \\
(\%)\end{array}$ & & \\
\hline & $366(33.5)$ & $179(16.4)$ & $547(50.1)$ & & \\
\hline \multirow[t]{2}{*}{ Psychological Impact } & No change $n(\%)$ & Worse n $(\%)$ & $\begin{array}{l}\text { Much worse } \\
\mathrm{n}(\%)\end{array}$ & $\begin{array}{l}\text { Better } n \\
(\%)\end{array}$ & $\begin{array}{l}\text { Much } \\
\text { better } n \\
(\%)\end{array}$ \\
\hline & $230(21.1)$ & $494(45.2)$ & $209(19.1)$ & $\begin{array}{l}125 \\
(11.4)\end{array}$ & $34(3.1)$ \\
\hline
\end{tabular}

3.3 Availability and accessibility of Internet and logistics for online class

Most of the students 827 (76\%) had internet access at their residence whereas $265(24 \%)$ students have no internet access at their residence. Half of the students 551(50.5\%) did not have good enough speed for online classes and $374(34.2 \%)$ students have sufficient internet speed for attending online classes. About half of the respondents 526 (48\%) were equipped with sufficient devices to attend online classes whereas $460(42.1 \%)$ students did not have proper equipment to attend online classes. A large number of students, $519(47.5 \%)$ were not being able to bear the expenses of the internet due to the financial crisis and $420(38.5 \%)$ of the students were able to bear the expenses of the internet. On the other hand, $153(14.0 \%)$ of the respondents were not sure if they were being able to bear the expenses of the internet. But the majority of respondents $653(59.8 \%)$ were not interested to attend the online classes whereas $439(40.2 \%)$ of the respondents were prepared to attend online classes (Table 3 ). 
Table 3. Internet access, quality and devices for online classes.

\begin{tabular}{|c|c|c|c|}
\hline Internet Access & Yes n (\%) & No n (\%) & \\
\hline & $827(75.7 \%)$ & $265(24.3 \%)$ & \\
\hline Sufficient Speed of Internet & Yes n (\%) & No n (\%) & Not sure n (\%) \\
\hline & $374(34.2)$ & $551(50.5)$ & $167(15.3)$ \\
\hline Sufficient Device & Yes n (\%) & No n (\%) & Not sure (\%) \\
\hline Ability to Bear the internet Expenses & $526(48.2)$ & $460(42.1)$ & $106(9.7)$ \\
\hline & Yes n (\%) & No n (\%) & \\
\hline & $420(38.5)$ & $519(47.5)$ & $153(14.0)$ \\
\hline Interested for Online Classes & Yes n (\%) & No n (\%) & \\
\hline & $439(40.2)$ & $653(59.8)$ & \\
\hline
\end{tabular}

\section{Limitations}

Current study will be landmark study in these regions and the findings will help the social scientist as well as the policy maker to develop future intervention. Due to shorter duration of time and limited resources, the country wide study could not be done among all the private University students. The greatest limitation was accessing all of the public University especially those without phones and for the short period of time.

\section{Discussion}

This study is the comprehensive study to elucidate the depth extent of the impact of COVID-19 on students of public universities of Bangladesh only but also the explored the capacity to combat the current devastating pandemic.

This study extended up to the students who had mobile network, so we could have extended the opinion up to the student who had neither smartphone nor internet. This study included 1092 students of 15 universities by convenience sampling that is representative of about 300000 students of 37 public universities (The University Grant Commission of Bangladesh, 2019). A majority of the students were under graduate 859 (79\%) who responded to this survey, this finding also validates the representative sampling of the students of public universities of the country where most of the students are in undergraduate courses. The predominant respondents were male $732(67.4 \%)$, whereas female respondents were $354(32.6 \%)$. This gender inequality is similar to male female ratio of 1.96: 1 published by the University Grant Commission of Bangladesh (2019). This indicates female empowerment by education for Bangladesh is yet to be reached.

Half of the respondents bear their educational or general living expenses by themselves and significantly higher number of male students shoulder their full expenses (p-value 000), though $33(9.3 \%)$ female students had to manage their full expense. One third of female respondents earned to bear their educational and living expenses partially. This clearly indicates female empowerment and independent decision making is evolving in positive way among the students of public universities of Bangladesh. The Women Economic Empowerment (WEE) report focuses on the barriers and opportunities related to the economic empowerment of women where education is mentioned as one of the most important determinants of empowerment following (The World Bank, 2018 ; Sultana, 2011; Schuler \& Rottach, 2010). Opportunities for female education offered by the government of Bangladesh escalated this better impact. About half of the respondents $489(45 \%)$ of the students had a private tuition or part time job of them male students were 347 (47.4\%) and female were138 (39.0\%). Significantly higher number of male students were involved in private tuition or part time job. Those students bearing their educational expenses, having part time jobs will off course suffer financially during online class and will have to overcome this barrier for effective online class.

This study revealed that almost $50 \%$ of the respondents confronted COVID-19 positive patient in their neighborhood. This indicates the devastating community transmission is on the way to peak explosion of the disease. This also justify the relevancy of the research in this field and necessitates the exploration of the ways to minimize the impact of COVID-19. 
The average study hour before pandemic was (mean \pm SD) $3.67 \pm 2.17$ hours and was similar for male and female students. This indicates poor interest of our university student for study. This warrant further modification of our curriculum to make the education to be of interest for students that would be employment or performance based (Tam, 2014; Barbosa et al., 2017). It is very important to notice that there has been a significant decrease in the study time of the students compared to the time they studied before the pandemic. The sudden interruption in their education due to COVID-19 has had a negative impact in their life and studies for $557(51 \%)$ of the respondents and $372(34.1 \%)$ of the respondents have had an extremely negative impact in their life and studies due to the discontinuity (Goldstein, 2020). This finding is the beginning of bitter experiences by this pandemic on human society. Several studies and UNESCO elucidated similar results (United Nations Educational, Scientific and Cultural Organization. 2020; Hess 2020; Burgess \& Sievertsen, 2020). This impose the responsibility to educationist, civil society, stalk holders and above all the state to find out several ways to overcome the situation. This study is as a part of those.

Nearly half of the respondents $504(46.2 \%)$ had a negative impact in their career planning and an extremely negative impact for $349(32.0 \%)$ of the students. Discontinuation of the study will create session jam, a good number of students will expire their age of entrance for public service. The number of unemployment population for Bangladesh is 2.6 million and unemployment rate 4.2 according to Bangladesh Bureau of Statistics (2018). Impact of COVID-19 will further add unemployment crisis for the country. This finding justifies the necessity of this study.

This study found that most of the respondents 805 (73.7\%) income was decreased during this catastrophe. In this survey due to COVID19 about (75.2\%) of the student have lost their part time job/private tuition for which about $63 \%$ of the respondents are in a financial crisis which has also affected their mental and psychological wellbeing. This study revealed that nearly half $45.2 \%$ of the respondents psychological status was worsen. A large number of Bangladeshi students are studying in universities who are currently in financial crisis and are very worried about tuition in the coming days. These findings are in association with a lot of national and international studies ((United Nations Educational, Scientific and Cultural Organization, 2020; World Health Organization, 2020; Miah et al., 2020). A recent study of Bangladesh Rural Advancement Committee (2020) revealed that due to COVID-19 pandemic about $95 \%$ people in Bangladesh went through a huge loss in their income. This finding justifies the necessity of this study.

Prevalence of psychological disruption estimated of depression, anxiety, and stress were $62.9 \%, 63.6 \%$, and $58.6 \%$, respectively in a recent study from Bangladesh (Islam et al., 2020). These core findings immediately necessitate intervention by the state to minimize the adverse events. The educational, financial and psychological crisis may lead to frustration of the demographic dividend of the country which would be ended up with suicide, addiction, criminal activities and anything else.

A various number of students in Bangladesh are yet to be graduated this year and try to enter the job market. Presently many companies are going into hiring freeze and lays-offs and some have declined their offers made to candidates. While the quick career pathway looks troublesome and somber for the fresh youthful talents, they could use this as a learning. Someone who is going to achieve the post corona virus - world will be able to be habituated to any kind of workplace with the ability to continuously update and refresh their skills.

In the midst of every one of these difficulties and openings, by what method should the young generation and the graduating students prepare themselves to adapt and embrace the changing job market, employment and skill development? There are unending free and open online courses accessible that will assist them with improving their skills and be more resilient in crisis and problematic situations (Mehjabeen, 2020).

Distant learning, online classes may be an option to reduce the negative impact of the COVID-19. A distance lesson over a video conference during the COVID-19 pandemic in Russia was effectively established. In response to the pandemic, many Educational institutions moved to online distance learning via platforms like Zoom (Centers for Disease Control and Prevention (CDC), 2020). To explore the feasibility of distant learning we have estimated the opportunity, accessibility, quality of internet services and devices in this study. This study also assessed the financial capacity of the students to avail the online class facility from their residences at urban or deep rural area of the country. Surprisingly most of the students $827(76 \%)$ had internet access at their residence whereas 265 (24\%) students have no internet access at their residence.

UGC conducted a survey on many to find out the effectiveness of online classes compared to normal classes in higher education institutions. A total of around 19000 students and 7000 teachers participated in the survey. UGC found that almost $87 \%$ of the students have their own smartphones. However, the students complained that they faced a lot of problems while facing online classes due to high internet cost and poor speed. A similar report was 
published by a non-government organization. In a case report of same newspaper described as a student living in Sirajgonj who studies in Dhaka universities told the news that it is not possible for his family to buy internet using even 50 Taka. His dad does not have a job and he used to have a part-time job which was also stopped due to the pandemic (Sharifuzzaman \& Ahmed ,2020).

This study revealed that a large number of students $519(47.5 \%)$ were not being able to bear the expenses of the internet due to the financial crisis and only $420(38.5 \%)$ of the students were able to bear the expenses of the internet, rest could be able to bear the expenses partially. So at least $60 \%$ students need subsidy to start online classes.

Rich and poor students from various parts of the country study in public universities. Many of the students do not have the ability to use digital methods to do online classes and some students do not have the financial capacity to purchase devices to attend online classes.

Throughout the world, many teachers and students have been excited by the move to the online delivery mode. Online teaching is not a new mode of delivery for any university. Many faculty members get training to use online learning platforms either as the only delivery mode or as an add-on to face-to-face teaching. Moreover, there is always a chance that some faculty who are not good with technology will not be able to keep up with this mode (Sahu, 2020).

In the Philippines, due to the COVID-19 pandemic really causes a massive impact in higher educational institutions. The country immediately opted for online learning. Some teachers recorded and uploaded their lessons online for the students to access and some were even more innovative (Fox, 2007) and used Google Classrooms, Web Quest, and other online sites (Toquero,2020).

Although there are lot of challenges against the online classes but must be started in higher education institutions. But what are the main obstacles on the way? The main findings are the inability to bear the internet expenses and unavailability of devices. Most of the time an average smartphone is within USD\$ 82 to USD\$ 94 in the markets with which the students can attend online classes. According to this study out of 300,000 students about $30 \%$ students required subsidy for devices that is estimated about USD $\$ 8,470,588$. This study also revealed about $60 \%$ students are not capable to bear the internet expenses. So, if estimated subsidy for internet expense is USD \$ 4/month/ student it will require about USD\$ 7,623,529 for one year. So to start on line class for public university students total about USD $\$ 16,094,118$ subsidy is essential.

\section{Conclusion}

In conclusion this study explored that COVID-19 negatively impacted on educational, financial and psychological aspects of students of public universities of Bangladesh. As the ending of COVID -19 is uncertain. Following the developed world on line class is the only options to overcome the challenges with limitations of internet access and sufficient devices. To curb these impacts, public universities must provide financial subsidies to those disadvantaged and poor students to ensure the success of the online class. A large amount of subsidies USD \$ $16,094,118$ is strongly recommended to start and continue on line classes for next one year.

\section{Acknowledgements}

We wish to thank the students from 15 public Universities in Bangladesh who have spontaneously provided our questionnaire response. We are especially grateful to Professor Dr. Mohammad Main Uddin, Professor Dr. Rukshana Begum, University of Rajshahi, Bangladesh and Rahik Farhan who has always supported us with various suggestion in this regard.

\section{Disclosure statement}

No potential conflict of interest was reported by the authors.

\section{Funding}

This research was not funded and did not receive any financial aid. 


\section{References}

Askari, R.(2020, May 6). 'Education in the Time of Corona: What Should Universities Do?', The Daily Sun. https://www.daily-sun.com: https://www.daily-sun.com/amp/post/480321

Bangladesh Bureau of Statistics (BBS) (2018). Bangladesh Statistics 2018: Demographic and Social Indicators. Retrievedfrom https://bbs.portal.gov.bd/sites/default/files/files/bbs.portal.gov.bd/page/a1d32f13 $8553 \quad 44 \mathrm{f1} \quad 92 \mathrm{e} 6 \quad 8 \mathrm{ff} 8$ 0a4ff82e/Bangladesh $\% 20 \% 20$ Statistics-2018.pdf

Bangladesh Rural Advancement Committee (BRAC) (2020, June10). 95pc people suffer losses in income. Retrieved from http://www.brac.net/latest-news/item/1284-

Barbosa, J., Silva, A., Ferreira, M. A., \& Severo, M. (2017). The impact of students and curriculum on self-study during clinical training in medical school: a multilevel approach. BMC medical education, 17, 9. doi:10.1186/s12909-016-0846-3

Burgess, S., \& Sievertsen, H. H. (2020 April 1). Schools, skills, and learning: The impact of COVID-19 on education. Vox Eu. org. Retrieved from https://voxeu.org/article/impact-covid-19-education

Cambridge Assessment International Education (2020, March 23). Update from Cambridge International on May/June 2020 exams. Retrieved from

https://www.cambridgeinternational.org/news/news-details/view/update-from-cambridge-international-on-mayjune-2020-exams-20200323/

Centers for Disease Control and Prevention (CDC) (2020, April 10). Interim Guidance for Administrators of US K-12 Schools and Child Care Programs: Plan, Prepare, and Respond to Coronavirus Disease 2019 (COVID-19). Retrieved from https://www.cdc.gov/coronavirus/2019-ncov/community/schoolschildcare/guidance-for-schools.html\#

Directorate General of Health Services, Bangladesh (2020, May 18). National Guidelines on Clinical Management of Coronavirus Disease $2019 \quad$ (COVID-19). Retrieved from http://www.mohfw.gov.bd/index.php?option=com_docman\&task=doc_download\&gid=22424\&lang=en

Directorate General of Health Services (2020, 9 September). Retrieved from https://www.dghs.gov.bd/

Goldstein, D. (2020, June 5). 'Research Shows Students Falling Months Behind During Virus Disruptions', The New York Times. Retrieved from 2020 https://www.nytimes.com/2020/06/05/us/coronavirus-education-lost-learning.html.

Hess, A. (2020, April 30). Some students are considering dropping out of college because of coronavirus. https://www.cnbc.com/2020/04/28/students-are-dropping-out-of-college-because-of-coronavirus.html

Islam, M. S., Sujan, M. S. H., Tasnim, R., Sikder, M. T., Potenza, M. N., \& Van Os, J. (2020). Psychological responses during the COVID-19 outbreak among university students in Bangladesh. doi: $10.31234 /$ osf.io/cndz7

Knebel, E. (2001). The use and effect of distance education in healthcare: What do we know? Operations Research Issue Paper, 2(2), 1-24. Agency for International Development (USAID) by the Quality Assurance Project.

https://www.urc-chs.com/sites/default/files/DistanceEducation.pdf

Lisa Bender, (2020, March). Key Messages and Actions for COVID-19 Prevention and Control in Schools. https://www.who.int/docs/default-source/coronaviruse/key-messages-and-actions-for-covid-19prevention-and-control-in-schools-march-2020.pdf?sfvrsn=baf81d52_4

Mazumder, H. Q. (2014). Analysis of Quality in Public and Private Universities in Bangladesh and USA. International Journal of Evaluation and Research in Education (IJERE), 3 (2), 99-108, ISSN: 2252-8822. http://dx.doi.org/10.11591/ijere.v3i2.2886

Mehjabeen, M. (2020, May 11). 'Post-pandemic job market outlook: What industry leaders and experts think about Bangladesh', The Financial Express. Retrieved From https://thefinancialexpress.com.bd/views/views/post-pandemic-job-market-outlook-1589210806

Mustafa, N. (2020). Impact of the2019-20 coronavirus pandemic on Education. International Journal of Health Preferences Research. doi: 10.13140/RG.2.2.27946.98245 
Onyema, E. M., Anthonia, U.O., \& Deborah, E.C. (2019). Potentials of Mobile Technologies in Enhancing the Effectiveness of Inquiry-based Learning Approach. International Journal of Education (IJE), 2,1-25. doi:10.5121/IJE.2019.1421.

Onyema, E. M., Eucheria, N. C., Obafemi, F. A., Sen, S., Atonye, F. G., Sharma, A., \& Alsayed, A. O. (2020). Impact of Coronavirus Pandemic on Education. Journal of Education and Practice, 11 (13), 108-121. doi:10.7176/JEP/11-13-12

Rahman, K. R. \& Rahman, T. M. (2020, May 30). 'Challenges and considerations in overpowering COVID-19 pandemic in Bangladesh', Banglanews24.com.

Sahu, P. (2020). Closure of universities due to Coronavirus Disease 2019 (COVID-19): impact on education and mental health of students and academic staff. Cureus, 12(4). doi:10.7759/cureus.7541.

Schuler, S. R., \& Rottach, E. (2010). Women's empowerment across generations in Bangladesh. The journal of development studies,46(3),379-396.

Sharifuzzaman \& Ahmed. M. (2020, June 14). 'Government University: Session jam surrounds 8 lakh students', Prothom Alo.

Sultana, A. M. (2011). Factors effect on women autonomy and decision-making power within the household in rural communities. Journal of Applied Sciences Research, 7(1), 18-22. ISSN 1819-544X.

Tam, M. (2014). Outcomes-based approach to quality assessment and curriculum improvement in higher education. Quality Assurance in Education. https://doi.org/10.1108/QAE-09-2011-0059.

The University Grant Commission of Bangladesh (2019). 45th Annual Report 2018 (Publication No. 213 ISBN: 978-984-34-7466-7). UGC. Retrieved from http://www.ugc.gov.bd/

The World Bank (2018). Women Economic Empowerment Study, USA. Retrieved from http://documents1.worldbank.org/curated/en/861491551113547855/pdf/134846-WP-PUBLIC-march2-WB-Women-Study-EN.pdf

Toquero, C. M. (2020). Challenges and Opportunities for Higher Education amid the COVID-19 Pandemic: The Philippine Context. Pedagogical Research, 5(4), em0063. https://doi.org/10.29333/pr/7947

United Nations Educational, Scientific and Cultural Organization (UNESCO) (2020, April 29).1.3 billion learners are still affected by school or university closures, as educational institutions start reopening around the world. Retrieved from

https://en.unesco.org/news/13-billion-learners-are-still-affected-school-university-closures-educationalinstitutions

United Nations Educational, Scientific and Cultural Organization (UNESCO) (2020). Education: From disruption to Recovery. Retrieved 28 March

https://en.unesco.org/news/covid-19-educational-disruption-and-rezponse

United Nations Educational, Scientific and Cultural Organization (UNESCO) (2020, March 26). Global Education Coalition, COVID-19 Education Response. Retrieved from

https://en.unesco.org/covid19/educationresponse/globalcoalition

World Bank Group (2020, April 8). The COVID-19 Crisis Response: Supporting tertiary education for continuity, adaptation, and innovation. Retrieved from http://pubdocs.worldbank.org/en/621991586463915490/WB-Tertiary-Ed-and-Covid-19-Crisis-forpublic-use-April-9.pdf

World Health Organization (WHO) (2020, March 18). Mental health and psychosocial considerations during the COVID-19 outbreak. Retrieved from https://www.who.int/docs/default-source/coronaviruse/mental-health-considerations.pdf

World Health Organization (WHO) (2020, May 27). Clinical management of COVID-19: Interim guidance. https://apps.who.int/iris/bitstream/handle/10665/332196/WHO-2019-nCoV-clinical-2020.5eng.pdf? sequence $=1 \&$ isAllowed $=y$

Yee, C. P. (2020, May 8). COVID-19: Impact on the tertiary education sector in Malaysia. Crisis Assessment, Executive summary, Penang Institute, Retrieved from June 15, 2020, https://penanginstitute.org/wpcontent/uploads/2020/05/IMPACT-ON-THE-TERTIARY-EDUCATION-SECTOR-IN- 
MALAYSIA.pdf 